УДК 332.145

ББК 65.050

DOI $10.31554 / 2222-9175-2020-37-134-139$

3. Б.-А. Аондоков, Г. О. Борисов

ТЕРРИТОРИИ ОПЕРЕЖАЮЩЕГО

СОЦИААЬНО-ЭКОНОМИЧЕСКОГО РАЗВИТИЯ:

ОПЫТ АААЬНЕВОСТОЧНЫХ РЕГИОНОВ И ПЕРСПЕКТИВЫ ИХ СОЗААНИЯ В РЕСПУБАИКЕ БУРЯТИЯ

Показан анализ развития на Дальнем Востоке территорий опережающего социально-экономического развития (ТОСЭР). Определены основные проблемы их создания и функционирования. Обоснована необходимость использования режима ТОСЭР для реализации крупных инвестиционных проектов в отдаленных и малозаселенных территориях. Показана значимость строительства Мокской ГЭС для развития экономики зоны Байкало-Амурской магистрали. Разработано предложение по организации ТОСЭР на территории Муйского района Республики Бурятия.

Ключевые слова: особый правовой режим, Дальний Восток, Республика Бурятия, инфраструктура, территория, резиденты, инвестиционный проект, Мокская ГЭС, налоговые льготы.

\title{
Z. B.-D. Dondokov, G. O. Borisov \\ TERRITORIES OF ADVANCED SOCIAL AND ECONOMIC DEVELOPMENT: EXPERIENCE OF THE FAR EASTERN REGIONS AND PROSPECTS FOR CREATION IN THE REPUBLIC OF BURYATIA
}

The analysis of the development in the Far East of the territories of advanced social and economic development (TASED) is carried out. The main problems of their creation and functioning are identified. The necessity of using the TASED regime for the implementation of large investment projects in remote and sparsely populated areas is substantiated. The significance of the construction of the Mokskaya hydroelectric power station for the development of the economy of the Baikal-Amur Railway zone is shown. A proposal has been developed for organizing a TASED in the territory of the Muy district of the Republic of Buryatia.

Keywords: special legal regime, the Far East, the Republic of Buryatia, infrastructure, territory, residents, investment project, Mokskaya hydroelectric station, tax incentives.

В ключение Республики Бурятия в состав Дальневосточного федерального гиона. К решению проблем Бурятии подключаются дополнительные администра-

ДОНДОКОВ Зорикто Бато-Дугарович - доктор экономических наук, профессор, заместитель председателя Федерального государственного бюджетного учреждения науки «Бурятский научный центр СО РАН», главный научный сотрудник отдела региональных экономических исследований Федерального государственного бюджетного учреждения науки «Бурятский научный центр СО РАН» (Улан-Удэ, Россия). E-mail: dzorikto@mail.ru.

БОРИСОВ Геннадий Очирович- кандидат экономических наук, доцент, старший научный сотрудник отдела региональных экономических исследований Федерального государственного бюджетного учреждения науки «Бурятский научный центр СО РАН» (Улан-Удэ, Россия). Е-mail: borisovgo@bk.ru. 
тивные ресурсы (заместитель председателя Правительства России, Министерство РФ по развитию Дальнего Востока и Арктики). На территории республики начали действовать специальные институты социально-экономического развития субъектов РФ, входящих в состав ДФО: акционерное общество «Корпорация развития Дальнего Востока», автономные некоммерческие организации «Агентство Дальнего Востока по привлечению инвестиций и поддержке экспорта» и «Агентство по развитию человеческого капитала на Дальнем Востоке».

Республика Бурятия получила возможность использования новых инструментов развития экономики региона, важнейшим из которых является правовой режим территории опережающего социально-экономического развития (ТОСЭР). Создание и функционирование ТОСЭР регулируется соответствующим федеральным законом, принятым в конце 2014 г. [Федеральный закон... 2014].

Особый правовой режим осуществления предпринимательской деятельности включает в себя налоговые льготы, применение таможенной процедуры свободной таможенной зоны, приоритетное подключение к объектам инфраструктуры, особый режим государственного контроля и др. Государством оказывается значительная прямая поддержка по созданию территорий опережающего социально-экономического развития. Так, для формирования и развития инфраструктуры ТОСЭР из федерального бюджета за период с 2019 по 2021 г. планируется выделить 58,1 млрд руб. [Материалы заседания...].

Первые территории опережающего социально-экономического развития появились в 2015 г. на Дальнем Востоке. В отличие от особых экономических зон они были созданы под конкретных инвесторов по заявке региона. В настоящее время на территории ДФО создано 20 ТОСЭР, включая «Забайкалье» и «Бурятию» (табл. 1).

Таблица 1

Показатели развития ТОСЭР в ДФО*

\begin{tabular}{|c|l|c|}
\hline$№$ & \multicolumn{1}{|c|}{ Показатель } & Значение показателя \\
\hline 1 & Количество соглашений с резидентами ТОСЭР, ед. & 332 \\
\hline 2 & Заявленный объем инвестиций, млрд руб. & 2335,1 \\
\hline 3 & Число планируемых новых рабочих мест, тыс. & 57,4 \\
\hline 4 & Накопленный объем инвестиций резидентов ТОСЭР, млрд руб. & 235,2 \\
\hline 5 & Количество созданных рабочих мест, тыс. & 15,5 \\
\hline 6 & Число введенных в эксплуатацию проектов резидентов ТОСЭР, ед. & 83 \\
\hline
\end{tabular}
2019 г

* Информация АО «Корпорация развития Дальнего Востока» по состоянию на 19 марта

Наибольшее количество ТОСЭР (4) было создано в Приморском крае. По три территории опережающего социально-экономического развития образовано в Амурской и Сахалинской областях, а также в Хабаровском крае [Симутина, Харченкова 2018]. Следует отметить широкий диапазон отраслевой направленности ТОСЭР, включая сельское хозяйство, добычу полезных ископаемых, транспортнологистический комплекс, машиностроение и т. д. Большинство территорий опережающего социально-экономического развития характеризуются двумя и более видами экономической деятельности.

Наиболее масштабным проектом в дальневосточных ТОСЭР является строительство Амурского газоперерабатывающего завода (ТОСЭР «Свободный», Амурская область), который по мощности станет самым крупным в стране. Объем инвестиций по проекту составляет почти 1 трлн руб. 
Одно из крупнейших судостроительных предприятий России - судостроительный комплекс «Звезда» - предполагается создать в ТОСЭР «Большой Камень» (Приморский край). Частные инвестиции составляют 169 млрд руб. при бюджетных вложениях в размере 3,15 млрд руб. Планируется создать 5,5 тыс. рабочих мест [Территория опережающего развития...].

В целом за 5 лет, прошедших с начала создания первых ТОСЭР, накоплен пока еще небольшой опыт использования нового инструмента территориального развития. Вместе с тем уже можно делать определенные выводы.

Основные проблемы создания и развития ТОСЭР вытекают из отсутствия четкого механизма создания и функционирования территорий опережающего социально-экономического развития. Решения о создании ТОСЭР не всегда принимаются достаточно обдуманно, с обоснованными расчетами. В настоящее время отсутствуют методики отбора территорий для создания на них ТОСЭР, разработки и корректировки перспективных планов развития территорий опережающего социально-экономического развития и прилегающих поселений. К правовым проблемам следует отнести отсутствие документов, определяющих порядок осуществления контроля за выполнением резидентами ТОСЭР соглашений об осуществлении деятельности.

На наш взгляд, указанные проблемы вытекают из более глобальной проблемы отсутствия комплексной системы стратегического планирования на различных уровнях: федеральном, окружном (макрорегиональном), региональном, муниципальном. Недостаточная согласованность проектов, создаваемых в рамках ТОСЭР, с программами развития инвестиционной и предпринимательской деятельности субъектов РФ приводит к несбалансированности по ресурсам, нарушению сроков реализации и т. п.

Одной из наиболее острых проблем для создания новых производств является получение подходящего земельного участка. Вместе с тем до сих пор не упорядочена процедура оформления земельных участков, расположенных в границах созданных ТОСЭР, что приводит к задержке реализации инвестиционных проектов. Так, по данным аудитора Счетной палаты РФ Ю. В. Росляка, «...в аренду и собственность АО “Корпорация развития Дальнего Востока", осуществляющего функции управляющей компании ТОСЭР, передано только около 2 тыс. га, или менее 1 \% общей площади ТОСЭР» [2018].

Для большинства инвесторов существенным ограничением для создания новых производств является инфраструктурный вопрос. Стоимость и надежность инфраструктуры напрямую влияет на основные показатели бизнес-плана, детальная проработка которого начинается с подбора площадки и ее оснащения необходимыми коммуникациями.

Серьезной проблемой создания и развития ТОСЭР являются неравные условия экономической деятельности в регионе для резидентов и нерезидентов ТОСЭР при заведомо худших позициях последних. Она достаточно остро проявляется на территориях с высоким уровнем экономической активности, даже в моногородах.

На наш взгляд, ТОСЭР как особый правовой режим осуществления предпринимательской деятельности наиболее эффективен для реализации в отдаленных и малозаселенных территориях крупных инвестиционных проектов, связанных с освоением природных ресурсов, включая добычу, первичную переработку и перевозку полезных ископаемых, производство электроэнергии.

В Республике Бурятия создана ТОСЭР, границы которой определены в рамках территорий Кабанского и Кяхтинского районов. Потенциальными резидентами планируется реализация инвестиционных проектов по строительству птицеводческого комплекса и таможенно-логистического терминала с объемом частных инвестиций 
более 5,5 млрд руб. [Постановление... 2019]. Масштаб заявленных проектов в рамках ТОСЭР «Бурятия» весьма незначителен, по сравнению с проектами в других дальневосточных регионах. Необходимо использование указанного режима предпринимательской деятельности применительно к крупным инвестиционным проектам, которые могут внести существенный вклад в развитие экономики Бурятии. Таковым, по мнению авторов, является проект строительства Витимского гидроэнергетического комплекса на р. Витим [Дондоков, Борисов 2015].

Северо-восток Республики Бурятия является фактически единственной территорией Республики Бурятия, на которой не действуют экологические ограничения, связанные с воздействием особых режимов хозяйственной деятельности на Байкальской природной территории. По сути, данная территория является частью зоны Байкало-Амурской магистрали, включающей северные районы Республики Бурятия, Иркутской области и Забайкальского края, а также южные районы Якутии.

Этот район в перспективе может стать мощной индустриальной базой востока России, в основе которой лежат крупные инвестиционные проекты. Это, во-первых, Удоканский и Чинейский ГОКи в Забайкальском крае; во-вторых, Бодайбинский золоторудный район, включающий крупнейшее в России месторождение «Сухой лог» в Иркутской области; в-третьих, Орекитканский ГОК в Республике Бурятия. Актуален вопрос по модернизации действующей Байкало-Амурской магистрали. Для удовлетворения перспективных потребностей в электроэнергии предлагается строительство Мокской ГЭС на р. Витим, по которой проходит административная граница между Республикой Бурятия и Забайкальским краем.

При проектировании Мокской ГЭС учитывалось ее нахождение в центре перспективных нагрузок потребителей, удаленных от ближайших источников генерации электроэнергии - Усть-Илимской ГЭС (Иркутская область) и Нерюнгринской ГРЭС (Республика Саха(Якутия) - на расстояние более 1000 км. Это позволит обеспечить энергобезопасность севера Байкальского региона и комплексное решение проблем энергоснабжения. Строительство Витимского гидроэнергетического комплекса, включающего Мокскую ГЭС и Ивановский контррегулятор, обеспечит создание «энергетического моста» между объединенной энергосистемой Дальнего Востока и ЕЭС России. Реализация указанного проекта обеспечит создание новых рабочих мест в ходе строительства и эксплуатации ГЭС и связанных с ней объектов, поступление налогов в консолидированный бюджет Республики Бурятия, даст импульс социально-экономическому развитию севера республики.

Авторами рассматривались разные варианты реализации проекта строительства Мокской ГЭС, включение в различные программы и стратегии. Но в этих форматах очень сложно было их осуществлять. Реализация крупного инвестиционного проекта в отдаленных районах со сложными природно-климатическими условиями требует вложения значительных средств в объекты инженерной, транспортной, энергетической и социальной инфраструктуры.

Для строительства Мокской ГЭС, по мнению авторов, необходимо создание на территории Муйского района Республики Бурятия ТОСЭР. Именно этот правовой режим, на наш взгляд, является наиболее подходящим механизмом создания условий для реализации крупных инвестиционных проектов.

Гидроэлектростанция является крупным промышленным объектом с высокой долей условно-постоянных расходов и длительным сроком эксплуатации. По действующему законодательству ТОСЭР создается на 70 лет. Не меньший срок службы закладывается и в работу ГЭС. Стоимость больших гидроэлектростанций оценивается в десятки миллиардов рублей и составляет подавляющую часть затрат соответствующего инвестиционного проекта. Это важно в условиях использования режи- 
ма ТОСЭР, дающего возможность предоставления значительных налоговых льгот [Письмо... 2017]. Например, нулевая ставка налога на имущество организаций в течение 10 лет может обеспечить экономию инвестора до $22 \%$ от стоимости недвижимого имущества самой гидроэлектростанции и связанных с ней других объектов.

Не менее интересным для потенциальных резидентов ТОСЭР может стать и льготное налогообложение прибыли. В условиях низких текущих затрат, обусловленных отсутствием расходов на приобретение топлива, прибыль может быть значительной. В соответствии с действующим законодательством резиденту ТОСЭР может быть снижена ставка налога на прибыль организации. При гарантированном сбыте продукции крупным потребителям, включая БАМ и горнодобывающие предприятия, чистая прибыль может достигать миллиардов рублей.

Вместе с тем для создания ТОСЭР на базе Мокской ГЭС руководству Республики Бурятия необходим комплексный подход к развитию территории, предполагающий координацию деятельности заинтересованных сторон, включая органы государственной власти и бизнес-структуры, создание единого органа управления развития территории.

Первоочередной задачей является поиск потенциальных резидентов предполагаемой ТОСЭР и подготовка первичной документации. В дальнейшем необходимо проведение переговоров с потенциальными потребителями электроэнергии, а также с правительствами Забайкальского края, Иркутской области и Республики Саха (Якутия).

\section{Источники и литература}

Федеральный закон от 29 декабря 2014 г. № 473-Ф3 «О территориях опережающего социально-экономического развития в Российской Федерации».

Постановление Правительства Российской Федерации от 14 июня 2019 г. № 760 «О создании территории опережающего социально-экономического развития "Бурятия"».

Дондоков 3. Б.-Д. Хозяйственное освоение зоны БАМ: проблемы и перспективы комплексного освоения севера Байкальского региона / З. Б. Д. Дондоков, Г. О. Борисов // Региональная экономика. - 2015. - № 48. - С. 15-25.

Материалы заседания совета по вопросам развития Дальнего Востока и Байкальского региона при Совете Федерации 4 апреля 2019 г. [Электронный ресурс]. - Режим доступа: http:/council.gov.ru/media/files/lpUjmG4QB6H9MbsCWVPL2puO6pQVBCXx.pdf (дата обращения: 31.10.2019).

Письмо Департамента налоговой и таможенной политики Минфина России от 11 мая 2017 г. № 03-05-05-01/28335 «О предоставлении налоговых льгот резидентам территории опережающего социально-экономического развития» [Электронный ресурс]. - Режим доступа: https://minvr.ru/press-center/news/22521/ (дата обращения: 02.12.2019).

Росляк Ю. В. Механизм создания и функционирования территорий опережающего социально-экономического развития требует совершенствования / Ю. В. Росляк // Президентский контроль. - 2018. - № 7. - С. 41-44.

Симутина Н. Об оценке эффективности механизмов территорий опережающего развития Дальнего Востока / Н. Симутина, Е. Харченкова // Общество и экономика. - 2018. № 8. - С. 105-117.

Территория опережающего развития «Большой Камень» [Электронный ресурс]. - Режим доступа: https://priminvest.ru/tor/bolshoj-kamen/ (дата обращения: 29.11.2019).

\section{References}

Federal'nyj zakon ot 29 dekabrya 2014 g. № 473-FZ «O territoriyah operezhayushchego social'no-ekonomicheskogo razvitiya v Rossijskoj Federacii». 
Postanovlenie Pravitel'stva Rossijskoj Federacii ot 14 iyunya 2019 g. № 760 «O sozdanii territorii operezhayushchego social'no-ekonomicheskogo razvitiya «Buryatiya».

Dondokov Z. B.-D. Hozyajstvennoe osvoenie zony BAM: problemy i perspektivy kompleksnogo osvoeniya severa Bajkal'skogo regiona / Z. B. D. Dondokov, G. O. Borisov // Regional'naya ekonomika. - 2015. - № 48. - S. 15-25.

Materialy zasedaniya soveta po voprosam razvitiya Dal'nego Vostoka i Bajkal'skogo regiona pri Sovete Federacii 4 aprelya 2019 g. [Elektronnyj resurs]. - Rezhim dostupa: http://council. gov.ru/media/files/lpUjmG4QB6H9MbsCWVPL2puO6pQVBCXx.pdf (data obrashcheniya: 31.10.2019).

Pis'mo Departamenta nalogovoj i tamozhennoj politiki Minfina Rossii ot 11 maya $2017 \mathrm{~g}$. № 03-05-05-01/28335 «O predostavlenii nalogovyh l'got rezidentam territorii operezhayushchego social'no-ekonomicheskogo razvitiya» [Elektronnyj resurs]. - Rezhim dostupa: https://minvr.ru/ press-center/news/22521/ (data obrashcheniya: 02.12.2019).

Roslyak Yu. V. Mekhanizm sozdaniya i funkcionirovaniya territorij operezhayushchego social'no-ekonomicheskogo razvitiya trebuet sovershenstvovaniya / Yu. V. Roslyak // Prezidentskij kontrol'. - 2018. - № 7. - S. 41-44.

Simutina $N$. Ob ocenke effektivnosti mehanizmov territorij operezhayushchego razvitiya Dal'nego Vostoka / N. Simutina, E. Harchenkova // Obshchestvo i ekonomika. - 2018. - № 8. S. 105-117.

Territoriya operezhayushchego razvitiya «Bol'shoj Kamen'» [Elektronnyj resurs]. - Rezhim dostupa: https://priminvest.ru/tor/bolshoj-kamen/ (data obrashcheniya: 29.11.2019). 